\title{
La discusión sobre la supremacía del poder civil sobre las asociaciones religiosas en México en el Congreso Constituyente, 1916-1917
}

\author{
The discussion on the supremacy of civil power over religious \\ associations in Mexico in the Constituent Congress, 1916- 1917
}

Fernando Villegas Martínez

Universidad Autónoma de Zacatecas/Crónica de Guadalupe, Zacatecas-Mexico

\begin{abstract}
RESUMEN
El presente artículo analiza las discusiones en materia religiosa que se dieron en el congreso constituyente (1916-1917) que dieron como resultado la delineación de un marco normativo bastante restrictivo para las asociaciones religiosas y los ministros de culto. Se muestran las razones históricas y políticas que llevaron a los constituyentes a adoptar posturas anticlericales, imponiendo una visión en la que las Iglesias debían estar sometidas al poder civil, como una medida de sujetar política, económica y socialmente a las asociaciones religiosas, especialmente la católica. Se hace un seguimiento del proyecto inicial presentado por Venustiano Carranza sobre los artículos que regularían la cuestión religiosa, el debate que se generó y cómo quedó redactado en la Constitución. A su vez, se detalla qué pasó con el episcopado mexicano durante el movimiento revolucionario (1910-1917) y su posicionamiento sobre la Constitución de 1917.
\end{abstract}

Palabras clave: Constitución; Anticlericalismo; Revolución; Iglesia.

Editor: Sergio Paolo Solano. Universidad de Cartagena-Colombia.

Tipología IBN Publindex:

Artículo de Investigación

Copyright: $\odot$ 2020. Villegas, F. Este es un artículo de acceso abierto, distribuido bajo los términos de la licencia https://creativecommons.org/licenses/by-nc$\mathrm{sa} / 4.0 /$ la cual permite el uso sin restricciones, distribución y reproducción en cualquier medio, siempre y cuando que el original, el autor y la fuente sean acreditados.

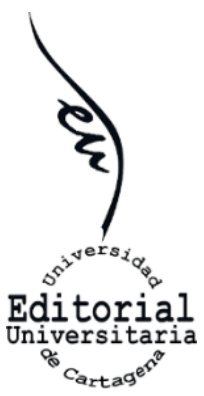

\begin{abstract}
This article analyzes the discussions in religious matters that took place in the Constituent Congress (1916-1917) and ended in the delineation of a rather restrictive regulatory framework for religious associations and ministers of worship. The historical and political reasons that led the Constituents to adopt anticlerical positions are manifested, imposing a vision in which the churches should be subjected to the civil power as a measure to dominate politically, economically and socially religious associations, specially the Catholic. A follow-up to the Initial Project presented by Venustiano Carranza was done, about the articles that would regulate religious issues, the debate that was generated and how it was written in the Constitution. At the same time, it details what happened to the Mexican episcopate during the revolutionary movement (1910-1917) and its position on the Constitution of 1917.
\end{abstract}

Key words: Constitution; Anticlericalism; Revolution; Church. 


\section{INTRODUCCIÓN}

La historia de las relaciones entre las Iglesias y el Estado en México es bastante extensa y diversa. Se han hecho estudios sobre el patronato regio indiano, análisis sobre las diferentes disposiciones estatales sobre los denominados bienes eclesiásticos, historias de instituciones educadoras de índole religiosa y, por su puesto, cómo se discutió la cuestión religiosa en los diferentes congresos constituyentes de los siglos XIX y XX. En ese sentido, sin duda que uno de los momentos fue sido la promulgación de la Constitución Política de los Estados Unidos Mexicanos (5 de febrero de 1917), dado que fue un producto directo del movimiento revolucionario (1910-1917), recogiendo las demandas populares de justicia social y proponiendo establecer una nueva dinámica en la que el Estado sería el principal agente de cambio político, social y económica. A su vez, la cuestión religiosa estuvo orientada a un ajuste de cuentas con la Iglesia católica, un histórico antagonista de la administración civil que, tal como pasó a mediados del siglo XIX, ocupó un sitio preponderante de los acusados de ser enemigos de la revolución. El presente artículo muestra cómo se presentaron, discutieron y aprobaron los diferentes artículos diseñados para regular la cuestión religiosa, siendo medidas que promovieron el sometimiento de las asociaciones religiosas al poder civil. A su vez, se retoma el posicionamiento de la Iglesia católica frente al embate anticlerical y a la Constitución de 1917.

El movimiento encabezado por Francisco I. Madero tomó Ciudad Juárez, Chihuahua, condicionando a Porfirio Díaz a formar los Tratados de Ciudad Juárez (21 de mayo 1911). Este acuerdo inédito tuvo consecuencias la agitación política de grupos que vieron la oportunidad perfecta para saltar a la arena de lo público. Los católicos capitalizaron las circunstancias para crear un partido político que representara sus intereses en el Congreso e sería "impregnar de la moral católica a la economía, y de lo que sería más valioso aún, la consecución de una restauración, es decir, la recuperación de espacios de donde se había excluido a Dios, el espacio público, la escuela y otros". ${ }^{1}$ De esta forma se creó el Partido Católico Nacional, el cual tuvo su primera experiencia electoral en 1911, apoyando a Madero en su candidatura presidencial. Además, el Partido Católico ganaría comisiones en el estado de Zacatecas, Jalisco y Estado de México. Todo cambiaría en febrero de 1913.

La revolución maderista, eminentemente política, no supo dar respuestas a las demandas sociales de los sectores agrarios e industriales. El cambio de régimen se había hecho únicamente con la sucesión presidencial. Los grupos

\footnotetext{
${ }^{1}$ Francisco Barbosa Guzmán, "Católicos y Revolución mexicana”, en Iglesia-Revolución mexicana. Jornada Académica, Guadalajara, Departamento de Estudios Históricos de la Arquidiócesis de Guadalajara/Dirección de Cultura del Ayuntamiento de Guadalajara, 2010, pp. 109-110.
} 
que otrora habían apoyado a Madero estaban descontentos. Emiliano Zapata demandaba "Tierra y Libertad", los grupos obreros regulación en las jornadas de trabajo, los sectores agrícolas el reparto agrario, los pueblos originarios la restitución de sus tierras. Demasiadas demandas que el presidente Madero no pudo dar respuesta oportuna. Había llamado a hacer la revolución en 1910, y la población esperaba respuestas. Hacia febrero de 1913, en medio de una ola de críticas hacia su administración, fue asesinado junto con el vicepresidente José Ma. Pino Suárez.

Quien estuvo detrás de las confabulaciones que llevaron a la muerte a Madero fue Victoriano Huerta con el apoyo de algunos militares porfiristas y el embajador de Estados Unidos en México, Henry Lane Wilson. En 19 de febrero de 1913 Victoriano Huerta fue nombrado presidente de México. Este hecho no fue bien recibido en algunos estados del país. De los 27 gobernadores "solamente cuatro: los de Sonora, San Luis Potosí, Aguascalientes y Coahuila, desconocieron a Huerta". ${ }^{2}$ Desde Coahuila, el gobernador Venustiano Carranza lanzó su Plan de Guadalupe (23 de marzo de 1913), en el cual se desconoció a Huerta como presidente, nombrándose así mismo como Primer Jefe del ejército constitucionalista. Se identificó a la Iglesia católica y al Partido Católico Nacional como colaboradores directos de la administración encabezada por Victoriano Huerta, por lo que no debe extrañarnos que los revolucionarios rápidamente transitaran de los señalamientos a las acciones hostiles con tintes francamente anticlericales. No era para menos, se les acusó de ser partícipes de las confabulaciones que llevaron a la muerte al presidente Francisco I. Madero y al vicepresidente José Ma. Pino Suárez el 22 de febrero de 1913.

Cabe aclarar que no todas las facciones revolucionarias adoptaron posturas netamente anticlericales. Si bien históricamente se ha identificado a los constitucionalistas como anticlericales, no todos los movimientos del norte del país compartieron esta tendencia. Como lo explica Adolfo Gilly, "en el norte, en donde la Iglesia era más débil, el párroco hasta podía ser un miembro estimado en la comunidad y, aunque hubo ejemplos de anticlericalismo villista, éstos eran esporádicos, y quizá se han exagerado". ${ }^{3}$ Se han identificado acciones de jefes villistas sobre ministros de culto y edificios religiosos, como pasó en la Batalla de Zacatecas (23 de junio de 1914), en donde "los revolucionarios decidieron tomar el edificio que desde 1878 había albergado al seminario...el edificio pasó a estar ocupado por las tropas revolucionarias, sirviendo como cuartel del 30 Batallón de Infantería

\footnotetext{
${ }^{2}$ Francisco L. Urquizo, Carranza. El hombre. El político. El caudillo. El patriota, México, SEP/INEHRM, 2015 , pp. 101. ${ }^{3}$ Alan Knight, "Caudillos y campesinos en el México revolucionario, 1910-1917”, en David Brading (Comp.), Caudillos y campesinos en la Revolución Mexicana, México, Fondo de Cultura Económica, 1985, pp. 72-73.
} 
correspondiente a la $11^{\mathrm{a}}$ zona militar". ${ }^{4}$ Sin embargo, el villismo no era sistemáticamente anticlerical ni antirreligioso. Un caso totalmente opuesto fue el movimiento encabezado por Emiliano Zapata. Lejos de sumarse a las hostilidades contra la Iglesia, "el zapatismo era abiertamente católico, al grado de admitir sacerdotes en sus filas y los zapatistas no eran los únicos revolucionarios populares que usaron y llevaron como bandera a las batallas la Virgen de Guadalupe"

Una vez que los revolucionarios se impusieron sobre el Ejército Federal y por consiguiente Victoriano Huerta dimitió y se exilió del país, lo que siguió fue la lucha de las diferentes facciones por imponer su primacía. Por un lado, existía un acuerdo entre villistas y zapatistas para luchar frente a los constitucionalistas, los cuales lograron sendas victorias en 1915, arrollando a las tropas mejor equipadas de Francisco Villa y en 1916 tomaron la ofensiva contra los zapatistas en Morelos. ¿Y qué pasó con la Iglesia católica durante el periodo de 1914-1917?

\section{1.- El exilio del episcopado mexicano}

Ante la hostilidad de los revolucionarios -especialmente los constitucionalistas- hacia la Iglesia católica, los ministros de culto y la jerarquía eclesiástica se preguntaron qué podían hacer. Ciertamente el ambiente anticlerical no era propicio para el ejercicio sacerdotal ni para la ministración de los sacramentos, y en algunos casos, incluso la vida estuvo de por medio. Ante el progresivo avance del Ejército Constitucionalista y la División del Norte - encabezada por Francisco Villa- hacia la capital del país, el episcopado mexicano entró en estado de alerta. Era de tomar una decisión. ¿Qué podían hacer frente a la actitud netamente anticlerical de los constitucionalistas?

En la Ciudad de México se empezaron a esparcir los rumores de las acciones que los constitucionalistas iban a emprender una vez que tomaran la capital del país: suspensión del culto, confiscaciones de templos y encarcelamiento/asesinato para los ministros de culto o bien. Ciertamente los temores estaban bien fundados dado que este tipo de acciones sí se habían llevado a cabo en algunos estados. Algunos prelados trataron de resguardarse en sus respectivas diócesis o en las ciudades más grandes del país, como la Ciudad de México o Guadalajara. Sin embargo, las condiciones políticas y militares no permitieron que la mayoría de los obispos tuvieran esta opción. La mayoría optó por el exilio a La Habana, Cuba, Estados Unidos o Europa.

\footnotetext{
${ }^{4}$ Fernando Villegas Martínez, "Tiempos difíciles", en Villegas Martínez, Fernando et al., La sabiduría se edificó una casa. Apuntes para la historia del Seminario Conciliar de Zacatecas, Zacatecas, Taberna libraria editores, 2019, p. 48.

${ }^{5}$ A. Knight, "Caudillos y campesinos", p. 72.
} 
A finales del mes de julio de 1914, un total de 12 obispos se encontraban en la Ciudad de México, tratando de esbozar una directriz general que les permitiera salir bien librados. La respuesta llegó desde Texas. El obispo de San Antonio, John W. Shaw ofreció recibir a los prelados que se encontraban en la capital del país. Tras el avance progresivo de los revolucionaros del norte al centro de México, la decisión pareció darse de forma natural y poco a poco fueron llegando los religiosos a Estados Unidos. ${ }^{6}$ La tabla 1 presenta el destino de cada uno de los obispos:

Tabla 1: El destierro del episcopado mexicano

\begin{tabular}{|c|c|c|}
\hline Arzobispos & $\begin{array}{l}\text { Periodo en el } \\
\text { cargo }\end{array}$ & Lugar del destierro \\
\hline México: José Mora y del Río & $1908-1928$ & La Habana, Cuba \\
\hline Michoacán: Leopoldo Ruiz y Flores & 1911-1937 & $\begin{array}{c}\text { Chicago, Estados } \\
\text { Unidos }\end{array}$ \\
\hline Guadalajara: Francisco Orozco y Jiménez & 1912-1936 & $\begin{array}{c}\text { Europa y Estados } \\
\text { Unidos }\end{array}$ \\
\hline Oaxaca: Eulogio Gillow y Zavala* & $1887-1922$ & Estados Unidos \\
\hline Durango: Francisco Mendoza y Herrera & 1909-1923 & Estados Unidos \\
\hline Puebla: Ramón Ibarra y González* & $1902-1917$ & $\begin{array}{l}\text { Permaneció en } \\
\text { México }\end{array}$ \\
\hline Linares: Francisco Plancarte & $1911-1920$ & Estados Unidos \\
\hline Yucatán: Martín Tritschler y Córdova* & 1900-1942 & La Habana, Cuba \\
\hline \multicolumn{3}{|c|}{ Obispos dependientes del arzobispado de México } \\
\hline Cuernavaca: Manuel Fulcheri & $1912-1922$ & No se sabe \\
\hline Chilapa: Francisco Campos Ángeles & $1907-1923$ & No se sabe \\
\hline Tulancingo: José Juan Herrera y Piña & $1907-1921$ & Estados Unidos \\
\hline Veracruz: Joaquín Arcadio Pagaza & $1895-1918$ & No se sabe \\
\hline \multicolumn{3}{|c|}{ Obispos dependientes del arzobispado de Michoacán } \\
\hline León: Emeterio Valverde Téllez & $1909-1948$ & Estados Unidos \\
\hline Querétaro: Manuel Rivera Muñoz & $1908-1914$ & No se sabe \\
\hline Zamora: José Othón Núñez y Zárate & 1909-1912 & No se sabe \\
\hline \multicolumn{3}{|c|}{ Obispos dependientes del arzobispado de Guadalajara } \\
\hline Aguascalientes: Ignacio Valdespino & $1913-1928$ & Estados Unidos \\
\hline Colima: Amador Velasco y Peña & 1903-1949 & No se sabe \\
\hline Tepic: Andrés Segura y Domínguez & 1906-1918 & No se sabe \\
\hline Zacatecas: Miguel M. de la Mora & $1911-1922$ & Estados Unidos \\
\hline \multicolumn{3}{|c|}{ Obispos pertenecientes al arzobispado de Oaxaca } \\
\hline Chiapas: Maximino Ruiz y Flores & $1913-1920$ & $\begin{array}{c}\text { Estados Unidos y } \\
\text { Guatemala }\end{array}$ \\
\hline Tehuantepec: Ignacio Placencia y Moreira & $1907-1922$ & No se sabe \\
\hline \multicolumn{3}{|c|}{ Obispos dependientes del arzobispado de Durango } \\
\hline Chihuahua: Nicolás Pérez Gavilán & 1902-1919 & No se sabe \\
\hline Sinaloa: Francisco Uranga Sáenz & 1903-1919 & Estados Unidos \\
\hline $\begin{array}{l}\text { Sonora: Ignacio Valdespino y Díaz } \\
\text { Juan María Navarrete }\end{array}$ & $\begin{array}{l}1902-1913 \\
1909 \text { en } \\
\text { adelante }\end{array}$ & $\begin{array}{l}\text { Estados Unidos } \\
\text { Estados Unidos }\end{array}$ \\
\hline
\end{tabular}

\footnotetext{
${ }^{6}$ Yolanda Padilla Rangel, Los desterrados. Exiliados católicos de la Revolución Mexicana en Texas, 1914-1919, Aguascalientes, Universidad Autónoma de Aguascalientes, 2009, pp. 70-74.
} 


\begin{tabular}{|l|c|c|}
\hline \multicolumn{3}{|c|}{ Arzobispos dependientes del arzobispado de Linares } \\
\hline Saltillo: Jesús María Echeverría y Aguirre & $1904-1955$ & Estados Unidos \\
\hline $\begin{array}{l}\text { San Luis Potosí: Ignacio Montes de Oca y } \\
\text { Obregón }\end{array}$ & $1884-1921$ & España \\
\hline $\begin{array}{l}\text { Tamaulipas: José de Jesús Guzmán } \\
\text { Sánchez }\end{array}$ & $1909-1914$ & No se sabe \\
\hline \multicolumn{2}{|c|}{ Obispos dependientes del arzobispado de Puebla } \\
\hline $\begin{array}{l}\text { Huajuapan de León: Rafael Amador } \\
\text { Hernández } \quad \text { Obispos pertenecientes al arzobispado de Yucatán }\end{array}$ \\
\hline \multicolumn{2}{|c|}{ No se sabe } \\
\hline \begin{tabular}{l|l} 
Campeche: Vicente Castellanos y Núñez \\
\hline Tabasco: Antonio Hernández y Rodríguez
\end{tabular} & $1912-1921$ & No se sabe \\
\hline Vicariato de Baja California & $1912-1922$ & \\
\hline
\end{tabular}

Fuente: Mario Ramírez Rancaño, La reacción mexicana y su exilio durante la Revolución de 1910, México, Instituto de Investigaciones Históricas Universidad Nacional Autónoma de México, 2002, pp. 76-77.

En suma, la mayoría del episcopado mexicano se encontraba en el exilio mientras se desarrollaba la última fase del movimiento revolucionario. Además, tuvieron que ver cómo una buena parte de los edificios sede de los seminarios de sus respectivas diócesis fueron confiscados, lo que también llevó a replantearse qué pasaría con la formación sacerdotal. En ese sentido, los seminarios intervenidos fueron los siguientes:

Tabla 2: Confiscaciones de los seminarios antes y durante la Revolución Mexicana

\begin{tabular}{|c|c|c|c|c|c|c|c|}
\hline \multirow[t]{2}{*}{ Fundación } & & \multirow{2}{*}{$\begin{array}{c}\text { Diócesis } \\
\text { Michoacán (I) }\end{array}$} & \multicolumn{5}{|c|}{ Confiscaciones } \\
\hline & & & & & & & \\
\hline & & Puebla & & 1867 & 1914 & 1928 & \\
\hline & & Chiapas & 1857 & & 1914 & 1925 & \\
\hline$(1572)$ & 1681 & Oaxaca & 1867 & & 1917 & & \\
\hline \multirow[t]{2}{*}{ (1570) } & 1696 & Guadalajara & 1861 & 1867 & 1914 & 1924 & \\
\hline & 1697 & México & 1861 & 1867 & 1914 & 1924 & \\
\hline \multirow[t]{3}{*}{ (1711) } & 1751 & Yucatán & 1861 & & & 1928 & \\
\hline & 1767 & Durango & 1860 & & 1914 & & \\
\hline & 1770 & Michoacán (II) & 1859 & 1867 & 1914 & 1928 & \\
\hline$(1712)$ & 1793 & Monterrey & 1862 & & 1914 & & \\
\hline \multirow[t]{2}{*}{ (1888) } & 1838 & Sonora & & & 1916 & 1932 & 1935 \\
\hline & 1855 & San Luis Potosí & 1859 & & 1914 & & \\
\hline \multirow[t]{2}{*}{ (1808) } & 1864 & León & 1861 & & 1915 & 1926 & \\
\hline & 1864 & Veracruz & & & & 1921 & \\
\hline \multirow[t]{3}{*}{ (185?) } & 1865 & Zamora & & & 1914 & & \\
\hline & 1865 & Tulancingo & & & 1914 & & \\
\hline & 1865 & Querétaro & & & 1914 & 1927 & 1932 \\
\hline \multirow[t]{3}{*}{ (1834) } & 1867 & Chilapa & & & & 1934 & \\
\hline & 1869 & Zacatecas & & & 1914 & & \\
\hline & 1873 & Tamaulipas & & & 1913 & 1927 & \\
\hline$(1845)$ & 1881 & Colima & & & 1914 & & \\
\hline \multirow[t]{4}{*}{ (1838) } & 1883 & Sinaloa & & & 1914 & 1926 & 1937 \\
\hline & 1891 & Saltillo & & & 1914 & & \\
\hline & 1892 & Tepic & & & 1914 & & \\
\hline & 1893 & Chihuahua & & & 1914 & & \\
\hline
\end{tabular}




\begin{tabular}{|c|c|c|c|c|}
\hline & 1894 & Cuernavaca & & 1925 \\
\hline & 1899 & Aguascalientes & 1914 & - \\
\hline \multirow[t]{4}{*}{ (1899) } & 1903 & Huajapán de León & 1914 & 1926 \\
\hline & 1905 & Tabasco & 1914 & \\
\hline & 1911 & Tehuantepec & 1914 & 1926 \\
\hline & 1920 & Tacámbaro & & 1926 \\
\hline (1924) & 1942 & Huejutla & & 1926 \\
\hline
\end{tabular}

Fuente: Yolanda Padilla Rangel, Los desterrados. Exiliados católicos de la Revolución Mexicana en Texas, 1914-1919, Aguascalientes, Universidad Autónoma de Aguascalientes, 2009, pp. 166-167.

Como pueden apreciarse, la mayoría de los seminarios fueron confiscados entre 1913-1917. En cuanto a los seminaristas, nuevamente serían los prelados estadounidenses quienes brindaron las facilidades necesarias para continuar con su formación. John W. Shaw y el padre A. Constantineu habían buscado la forma de ayudar económicamente a los obispos exiliados en Estados Unidos, por lo que también se acercaron a la Catholic Church Extension Society en búsqueda de ayuda en las gestiones de recaudación. El arzobispo de Chicago, Francis Edward Quigley, contactó al fundador y presidente de la asociación, monseñor Francis Clement Kelley, para solicitar donativos en varias ciudades estadounidenses. Kelley fue más allá de las pretensiones iniciales. Viajó a Cuba para reunirse con los obispos exiliados en ese país (José Mora y del Río (arzobispo de México), Martín Trischler (arzobispo de Yucatán) y Jesús Herrera y Piña (obispo de Tulancingo) para convencerlos de trasladarse a Estados Unidos. Únicamente Piña aceptó. Ya estando en Estados Unidos, le propuso a la Catholic Church Extension Society la formación de un seminario para los estudiantes mexicanos.

La otra opción que se tenía fue la de trasladar a los estudiantes a los diferentes seminarios que había en Estados Unidos, sin embargo, había 2 problemas: en primer lugar "los mexicanos no hablaban inglés; la segunda, porque transportar y financiar individualmente a las seminaristas en diferentes lugares resultaba más costoso que instalarlos a todos juntos en una sola casa, de preferencia cerca de la frontera de México, tal y como era el dese de los obispos mexicanos". ${ }^{7}$ La idea fue bien acogida por Kelley y Shaw, quienes negociaron con la Congregación de la Divina Providencia para que las religiosas cedieran el edificio que tenían en Castroville, Texas. Ahí se instaló el seminario de San Felipe Neri (1915-1918), el cual en los 5 años que estuvo en funcionamiento recibió a 108 estudiantes provenientes de las diócesis de Zacatecas (36), Tulancingo (16), Guadalajara (13), Querétaro (13), Yucatán (10), Saltillo (6), Zamora (6) Monterrey (3), Campeche (1), León (1), Durango (1) y Chiapas (1).

${ }^{7}$ Y. Padilla, Los desterrados, p. 169. 
Pese a que el seminario de San Felipe Neri representó una solución para la continuación de la formación sacerdotal, la medida no significó la solución a los problemas de la Iglesia católica. Hacia mediados de 1916, su funcionamiento regular había sido severamente mermado. Los seminarios habían suspendido sus actividades y los seminaristas regresaron a sus hogares -salvo los que se trasladaron al Seminario de San Felipe Neri-, además de que las actividades de culto público se encontraban suspendidas o bien, a merced de la autorización de los revolucionarios. Sin embargo, aún les esperaba otro golpe: mediante un decreto fechado el 14 de septiembre de ese año, Venustiano Carranza -en su calidad de Primer Jefe del Ejército Constitucionalista- convocó a que se conformara un Congreso Constituyente para elaborar un nuevo marco jurídico.

\section{2.- Una nueva Constitución}

Inicialmente, el Ejército Constitucionalista no se planteó como objetivo realizar una nueva Constitución, sino que la idea se fue madurando en el transcurso del movimiento revolucionario. En el Plan de Guadalupe (1913) se prometió "restaurar el orden constitucional interrumpido por la traición". 8 Pero una cosa es restaurar el orden constitucional de 1857 y otro muy diferente crear uno nuevo. Cuando los constitucionalistas vencieron a los villistas y zapatistas, lo que seguía era refrendar esa victoria armada con una de corte legal. En el mencionado decreto quedó establecida la dinámica a seguir: Carranza presentaría un proyecto de Constitución, el cual sería leído y discutido por los constituyentes, ya sea para aprobarlo o hacerle las modificaciones/adhesiones correspondientes, contando con 2 meses para realizar todo lo anterior. Ese mismo 14 de septiembre de 1916 se publicó la convocatoria para elegir a los diputados que se congregarían en la ciudad de Querétaro con la encomienda de dotarle al país una nueva Constitución.

Los diputados electos iniciaron los trabajos el 1 de diciembre de 1916. El primer acto fue la presentación del Proyecto de Reformas a la Constitución de 1857 y una explicación en voz del mismo Venustiano Carranza. En ese sentido, las diferencias más sustanciales del proyecto "estaban en lo político: no reelección, sufragio directo, supresión de la vicepresidencia, entre otros. Se incluían también algunos puntos sobre educación laica, libertad religiosa, trabajo colectivo de las tierras ejidales, hasta que fueran divididas por la ley." 9 Como ya se ha mencionado, durante la segunda mitad del siglo XIX, el Estado mexicano impuso severas restricciones a las Iglesias y ministros de culto, sin embargo, dado que la Iglesia católica fue señalada como colaboradora de la administración huertista, los diputados no dudaron en llevar el

\footnotetext{
${ }^{8}$ Francisco L. Urquizo, Carranza. El hombre. El político. El caudillo. El patriota, México, SEP/INEHRM, 2015, p. 42.

${ }^{9}$ Nicolás Cárdenas García y Enrique Guerra Manzo, "De revolucionarios a legisladores. El proceso político del Congreso Constituyente de 1916-1917", en Política y Cultura, No. 48, 2017, p. 25.
} 
anticlericalismo al nuevo marco legal. De esta forma, la cuestión religiosa cobró relevancia en los debates del Congreso Constituyente, ya no para delimitar la presencia de las asociaciones religiosas en los ámbitos público y privado, sino para someterlas definitivamente al poder civil.

\subsection{La educación será laica, gratuita y obligatoria: artículo. 3}

El tema educativo ha sido históricamente un asunto de discusión constante entre el Estado y las asociaciones religiosas, especialmente la católica. En la Constitución de 1857 quedó asentada que la "enseñanza será libre", y que sería la ley quien determinaría cuáles profesiones necesitarían título para su ejercicio y los requisitos para su expedición. En leyes posteriores se incluyó la gratuidad y obligatoriedad de la educación, así como asentar la educación laica, con el claro objetivo de romper el monopolio que en este rubro tenía la Iglesia católica. En ese sentido, "la transición de la moral secular a la escuela laica se desarrolló en explícita oposición a la religiosa, ya que uno de los valores centrales de esta moral secular fue la libertad individual, concebida como autonomía"10, en donde el Estado asumió la tarea de convertirse en educador y guía moral.

Los constituyentes que se habían dado cita en Querétaro revisaron cómo se delineó la participación del Estado y de la Iglesia en el ámbito educativo en las legislaciones anteriores. En el proyecto presentado por Carranza se reprodujo el artículo $3^{\circ}$ de la Constitución de 1857. Su idea no fue aceptada por los diputados, iniciándose las discusiones al respecto. "El debate fue largo y profundo, de esta suerte se hicieron presentes aspectos pedagógicos, jurídicos y políticos, en cuyos argumentos constantemente aparecieron alusiones históricas y de derecho comparado"11, quedando aprobada una nueva versión del artículo $3^{\circ}$ :

La enseñanza es libre; pero será laica la que se dé en los establecimientos oficiales de educación, lo mismo que la enseñanza primaria, elemental y superior que se imparta en los establecimientos particulares.

Las escuelas primarias particulares sólo podrán establecerse sujetándose a la vigilancia oficial.

En los establecimientos oficiales se impartirá gratuitamente la enseñanza primaria. ${ }^{12}$

La ley limitó severamente a las instituciones particulares en el ámbito educativo al imponer la laicidad en los niveles primaria, elemental y superior.

\footnotetext{
${ }^{10}$ María del Refugio Magallanes Delgado, La educación laica en México. La enseñanza de la moral práctica XIX-XX, Zacatecas, Policromía, 2016, p. 23.

Antonio Soto Flores, "El artículo $3^{\circ}$. Constitucional. Un debate por el control de las conciencias", en Cuestiones Constitucionales. Revista Mexicana de Derecho Constitucional, No. 28, 2013, p. 215.

12 "Constitución Política de los Estados Unidos", p. 149.
} 
En ese sentido, el Estado se reservó para sí el deber de formar a las nuevas generaciones bajo una moral secularizada, señalando la gratuidad -sólo para el nivel básico- y laica en sus contenidos. Mientras que para los establecimientos particulares estarían supeditados a la supervisión estatal, tanto en la obtención del permiso correspondiente, como en la revisión de sus contendidos. Por último, el que "por ningún motivo se revalidará, otorgará dispensa o se determinará cualquier otro trámite que tenga por fin dar validez en los cursos oficiales, a estudios hechos en los establecimientos destinados a la enseñanza profesional de los ministros de los cultos"13, repercutiría en la invalidez de los títulos expedidos por las instituciones de formación religiosa, directriz enfocada directamente a los seminarios.

\section{3.- Continúa la supresión de las órdenes monásticas}

Otro tema fue el relacionado con la existencia del clero regular. Desde finales del siglo XVIII se cuestionó la presencia de las órdenes religiosas y los numerosos conventos -tanto masculinos como femeninos-. A mediados del siglo XIX y específicamente durante la Reforma Liberal (1856-1867), el Estado impulsó severas consideraciones hacia las órdenes, siendo las que más resintieron la desamortización/nacionalización de bienes eclesiásticos. Ya el 26 de febrero de 1863 el Estado había decretado la supresión de las comunidades religiosas en todo el país, situación que fue refrendada en la Ley Orgánica de 1874. En el proyecto presentado por Carranza se confirmó lo anterior en el tenor siguiente:

Nadie podrá ser obligado a prestar trabajos personales sin la justa retribución y sin su pleno consentimiento, salvo el trabajo impuesto como pena por la autoridad judicial. En cuanto a los servicios públicos, sólo podrán ser obligatorios en los términos que establezcan las leyes respectivas, el de las armas, los de jurado y los cargos de elección popular, y obligatorias y gratuitas, las funciones electorales. El Estado no puede permitir que se lleve a efecto ningún contrato, pacto o convenio que tenga por objeto el menoscabo, la pérdida o el irrevocable sacrificio de la libertad del hombre, ya sea por causa de trabajo, de educación o de voto religioso. La ley, en consecuencia, no reconoce órdenes monásticas, ni puede permitir su establecimiento, cualquiera que sea la denominación u objeto con que pretendan erigirse. Tampoco puede admitirse convenio en el que el hombre pacte su proscripción o destierro, o en el que renuncie temporal o permanentemente a ejercer determinada profesión, industria o comercio. El contrato de trabajo sólo obligará a prestar el servicio convenido por un período que no exceda

13 “Constitución Política de los Estados Unidos”, p. 149. 
de un año, y no podrá extenderse en ningún caso a la renuncia, pérdida o menoscabo de cualquiera de los derechos políticos y civiles. ${ }^{14}$

Si bien sí existieron modificaciones referentes al ejercicio y regulación de las profesiones, protección de los trabajadores, limitación de horas de la jornada laboral, trabajo infantil y regulación del turno nocturno para las mujeres, no hubo discusiones acerca de refrendar el no reconocimiento de las órdenes monásticas, únicamente se modificó la redacción. Entre las intervenciones de los constituyentes, sobresalen las de Francisco Mújica y Alfonso Cravioto, quienes señalaron que el clero católico era enemigo de la lucha social y del pueblo, y que sus intereses estaban en tener más privilegios para gobernar de forma absoluta las conciencias. ${ }^{15} \mathrm{En}$ el dictamen del artículo $5^{\mathrm{o}}$ quedó asentado que la expresión "La ley no reconoce órdenes monásticas" parece ociosa, supuesta la independencia entre la iglesia y el Estado; cree adecuado la comisión substituir esa frase por esta: "La ley no permite la existencia de órdenes monásticas". También proponernos se suprima la palabra "proscripción", por ser equivalente a la de "destierro". ${ }^{16}$ De esta forma, el Estado prohibió los votos monásticos y el establecimiento de las órdenes religiosas.

\subsection{Refrendo a la libertad de culto: artículo 24}

La libertad religiosa no fue un tema novedoso. Ciertamente desde que México se independizó de España se escucharon voces que pedían la no confesionalidad del Estado, para permitir el establecimiento de otras religiones. Durante los debates del constituyente de 1857, "la tolerancia religiosa era temida porque afectaba directamente a uno de los pilares del orden social: la Iglesia católica romana y porque contenía los gérmenes de las ideas políticas modernas, democráticas, individualistas, que amenazan el poder corporativo y patrimonial heredado de España". ${ }^{17}$ La pregunta que se puso sobre la mesa fue bastante clara ¿será conveniente atentar contra la unidad religiosa de México? El 29 de julio de 1856, Marcelino Castañeda, gobernador de Durango y ministro de Justicia y Negocios Eclesiásticos, expuso que los representantes de pueblo no podían atentar contra la comunión que tiene el país con la religión, agregando que:

El pueblo no quiere conocer otra religión que la católica, el ama con entusiasmo las ceremonias solemnes y majestuosas de nuestro culto, saca del fondo de los templos su consuelo, sus esperanzas, su alegría.

\footnotetext{
${ }_{14}^{14}$ Pastor Roauix, Génesis de los artículos 27 y 123 de la Constitución Política de 1917, México, INEHRM, 2016, pp. 9394.

${ }^{15}$ Félix F. Palavicini, Historia de la Constitución de 1917, México, SEP/INEHRM, 2015, t. I, pp. 297-316.

${ }^{16}$ P. Roauix, Génesis de los artículos, p. 97.

17 Jean Pierre Bastian, Los disidentes. Sociedades protestantes y revolución en México, 1872-1911, México, Fondo de Cultura Económica/El Colegio de México, 1989, p. 27
} 
Tiene complacencia en postrarse ante Dios en las calles y plazas, en rendirle homenajes públicos, en adorarle a la faz de todos, y ahora quiere quitársele su placer, su delicia, su entusiasmo; se quiere que su Dios quede oculto en los templos y que no se le tributen adoraciones en las calles y plazas; se quieren destruir esas solemnidades públicas en que todo un pueblo se prosterna ante la Majestad Divina; se quiere poner a nuestro Dios al nivel de las divinidades fingidas; se quiere presentarlo como avergonzado y oculto y que sea desconocido en lo público... Esto, señores, es una injusticia, es una crueldad... Si sois demócratas, respetad la voluntad de ese pueblo; si sois liberales, dejadlo disfrutar de su libertad, dejadlo gozar de su consuelo, de sus delicias, de su felicidad. ${ }^{18}$

No existió una intención tácita de atacar frontalmente a la Iglesia católica, sin embargo, pese al posicionamiento moderado de los diputados frente a la tolerancia religiosa, esta propuesta "fue abandonada se buscó llegar a un arreglo en la redacción del artículo 123. En dicho artículo se le reconocía al gobierno la autoridad (en forma de patronato) sobre la Iglesia y se le otorgaba el derecho de intervenir en asuntos religiosos". ${ }^{19}$ La tolerancia religiosa en México pudo ser posible a partir de la expedición de la Ley Libertad de Cultos (1860), siendo refrendada en 1873 y 1874. El debate del artículo 24 en el congreso constituyente estuvo marcado por ampliar las limitaciones a las asociaciones religiosas y las actividades de culto público. Se refrendó la tolerancia religiosa y la vigilancia de la autoridad sobre los actos religiosos de culto público, que debían llevarse a cabo dentro de los templos. El diputado Enrique Recio señaló que para completar el artículo 24 se debían agregar las fracciones siguientes: "I. Se prohíbe al sacerdote de cualquier culto, impartir la confesión auricular," "II. El ejercicio del sacerdocio se limitará a los ciudadanos mexicanos por nacimiento, los cuales deben ser casados civilmente, si son menores de cincuenta años de edad". ${ }^{20}$ Sin embargo, estas restricciones propuestas se trasladaron a los debates sobre el proyecto del artículo 129, quedando el 24 orientado a garantizar la libertad de cultos:

Todo hombre es libre para profesar la creencia religiosa que más le agrade y para practicar las ceremonias, devociones o actos del culto respectivo, en los templos o en su domicilio particular, siempre que no constituya un delito o falta penada por la ley.

Ningún acto religioso de culto público deberá celebrarse fuera del interior de los templos, los cuales estarán siempre bajo la vigilancia de la autoridad. ${ }^{21}$

\footnotetext{
${ }^{18}$ Francisco Zarco, Historia del Congreso Extraordinario Constituyente de 1856 y 1857: extracto de todas sus sesiones y documentos parlamentarios de la época. México, Imprenta de Ignacio Cumplido. 1857. Tomo 1, pp. 771-776.

${ }^{19}$ J. P. Bastian, Los disidentes, p. 29.

${ }^{20}$ Francisco J. Rodríguez Carvajal, "La libertad religiosa en las Constituciones de 1857 y 1917”, en Quórum legislativo. Revista del Centro de Estudios de Derecho e Investigaciones Parlamentarias, No. 118, 2017, p. 138.

${ }^{21}$ Alonso Lara Bravo, Libertad religiosa en México, México, Comisión Nacional de Derechos Humanos, 2015, pp. 29-30.
} 
Se circunscribieron los actos religiosos al interior de los templos, limitando las expresiones/manifestaciones populares con profundo arraigo en la población. Aunque ese aspecto fue regulado en el artículo 130.

\section{4.- Se nacionalizan los bienes de las asociaciones religiosas: fracción II del artículo 27}

El tema de los bienes raíces de las asociaciones religiosas no fue novedoso. Ya desde mediados del siglo XVIII la monarquía española había promovido ciertas disposiciones sobre inmuebles administrados por la Iglesia católica. Durante la época independiente, el asunto se volvió cada vez más recurrente, cada que el Estado veían caídas en la recaudación o pretendía solicitar un préstamo, se volteó a ver a los bienes eclesiásticos. Esta constante hizo que se escucharan cada vez más las voces que plantearon hacer reformas sobre la regulación de la propiedad eclesiástica. Finalmente, la Revolución de Ayutla (1854) que puso fin al último periodo presidencial del controvertido Antonio López de Santa Anna coadyuvó a proponer modificaciones sustanciales a las dinámicas que el Estado sostenía sobre los bienes eclesiásticos. De esta forma, el 23 de junio de 1856 se publicó la Ley de Desamortización de las Fincas Rústicas y Urbanas de las Corporaciones Civiles y Religiosas de México -mejor conocida como Ley Lerdo-, en la cual "la élite política liberal se propuso forjar una sociedad de mercado formada por individuos productores y consumidores con derechos políticos y de propiedad individual, y eliminar los bienes amortizados a perpetuidad, no enajenables que poseían las corporaciones". ${ }^{22}$

Se trató de un proyecto que pretendía circular el capital raíz que estaba en manos de las corporaciones -mayoritariamente de la Iglesia católica-, propiciando así la creación de pequeños propietarios. Se debe aclarar que no todos los bienes de las corporaciones eran susceptibles a ser desamortizados, únicamente las "las fincas rústicas y urbanas que hoy tienen o administran como propietarios las corporaciones civiles y eclesiásticas de la República se adjudicarán en propiedad a los que las tienen arrendadas por el valor correspondiente a la renta que en la actualidad pagan, calculada como rédito al seis por ciento anual". ${ }^{23}$ Sobre las propiedades que no estuviesen arrendadas, se debían adjudicar al mejor postor. Se exceptuaron de la desamortización "los edificios destinados inmediata y directamente al

\footnotetext{
22 Daniela Marino y María Cecilia Zuleta, "Una visión del campo. Tierra, propiedad y tendencias de la producción, 18501930”, en Sandra Kuntz Ficker (coord.), Historia económica de México. De la colonia a nuestros días, México, El Colegio de México, 2010, p. 439.

23 "Decreto sobre desamortización de fincas rústicas y urbanas que administren como propietarios las corporaciones civiles y eclesiásticas”, en Manuel Dublán y José Ma. Lozano, (comp.), Legislación mexicana o colección completa de las disposiciones legislativas expedidas desde la Independencia de la República, México, Imprenta del Comercio de E. Dublán y Comp., t. VIII, 1877, p. 197.
} 
servicio u objeto del instituto de las corporaciones, aun cuando aun cuando se arriende alguna parte no separada de ellos, como los conventos, palacios episcopales y municipales, colegios, hospitales, hospicios, mercados, casas de corrección y la beneficencia". ${ }^{24}$ Tanto los templos como sus anexidades quedaron fuera de las medidas desamortizadoras al considerarse indispensables para el ejercicio/servicio de la corporación. También se agregó que, en lo sucesivo, ninguna corporación civil o eclesiástica, independientemente de su denominación u objeto, tendría capacidad legal para poseer/administrar para sí bienes raíces, salgo los que la misma ley exceptuó.

Durante el movimiento revolucionario, y a la par de las confiscaciones de templos, escuelas católicas, prohibición de la enseñanza religiosa, ocupación de seminarios y hostigamiento hacia miembros del clero, se empezó a cuestionar si es que las ya mencionadas Leyes de Reforma eran suficientes para inhibir la capacidad económica de las asociaciones religiosas, especialmente la católica. Si la legislación en materia religiosa de la segunda mitad del siglo XIX ya era bastante dura, los constituyentes trataron de ir más allá. Para empezar, se cuestionó el número de templos existentes en el país. Según Moisés González Navarro, hacia 1910 existían 12.658 templos en todo el país, de los cuales 12.413 correspondían al culto católico, mientras que los restantes 245 eran protestantes:

Tabla 3: Templos existentes en las entidades federativas, según cultos. Años de 1878 a 1910

\begin{tabular}{|l|c|c|c|c|c|c|c|c|}
\hline \multirow{2}{*}{$\begin{array}{c}\text { Entidad } \\
\text { federativa }\end{array}$} & \multicolumn{4}{|c|}{ Católicos } & \multicolumn{4}{c|}{ Protestantes } \\
\cline { 2 - 12 } & 1878 & 1895 & 1900 & 1910 & 1878 & 1895 & 1900 & 1910 \\
\hline Total & 4893 & 9580 & 12225 & 12413 & 37 & 189 & 188 & 245 \\
\hline Aguascalientes & 18 & 59 & 56 & 86 & & 2 & 2 & 3 \\
\hline $\begin{array}{l}\text { Baja } \\
\text { California }\end{array}$ & 17 & & 11 & 29 & & & & 2 \\
\hline Campeche & 56 & 250 & 187 & 187 & & & & \\
\hline Coahuila & 35 & 79 & 87 & 110 & & 21 & 12 & 23 \\
\hline Colima & 23 & 31 & 33 & 49 & & 1 & & \\
\hline Chiapas & 37 & 415 & 387 & 326 & & & & 2 \\
\hline Chihuahua & & 212 & 199 & 254 & & 5 & 7 & 1 \\
\hline $\begin{array}{l}\text { Distrito } \\
\text { Federal }\end{array}$ & 281 & 387 & 275 & 297 & 14 & 18 & 20 & 22 \\
\hline Durango & 49 & & 224 & 191 & & - & 5 & 6 \\
\hline Guanajuato & & 1009 & 1192 & 1336 & & 15 & 8 & 7 \\
\hline Guerrero & 361 & 526 & 577 & 443 & & 5 & 7 & \\
\hline
\end{tabular}

24 "Decreto sobre desamortización”, p. 197. Sobre el censo enfitéutico, se refiere a la cesión perpetua o por largo tiempo del dominio útil de una propiedad inmueble mediante el pago o pensión anual al que hace la cesión en concepto de reconocimiento de dominio útil de la finca. Se tomó el mismo criterio para el cálculo del valor del inmueble que en lo establecido en el artículo $1^{\circ}$. 


\begin{tabular}{|l|c|c|c|c|c|c|c|c|}
\hline Hidalgo & 483 & 833 & 877 & 711 & 2 & 15 & 13 & 12 \\
\hline Jalisco & 355 & 383 & 665 & 733 & & 8 & 8 & 5 \\
\hline México & & 1692 & 1516 & 1442 & & 36 & 33 & 35 \\
\hline Michoacán & & 145 & 627 & 587 & & 6 & & 1 \\
\hline Morelos & 255 & & 286 & 295 & 3 & & 8 & 12 \\
\hline Nuevo León & & 71 & 84 & 96 & & 9 & 13 & 18 \\
\hline Oaxaca & 1021 & 165 & 1312 & 1340 & & 2 & 4 & 9 \\
\hline Puebla & 1019 & 1299 & 1257 & 1371 & 11 & 13 & 4 & 15 \\
\hline Querétaro & 107 & 164 & 253 & 255 & & 2 & 1 & 1 \\
\hline Quintana Roo & & & & 6 & & & & \\
\hline San Luis & 171 & 314 & 222 & 319 & & 13 & 5 & 8 \\
\hline Potosí & & 103 & 108 & 121 & & 1 & & 12 \\
\hline Sinaloa & & 122 & 100 & 102 & & 2 & 6 & 17 \\
\hline Sonora & & 62 & 110 & 83 & & 4 & 4 & - \\
\hline Tabasco & 41 & & 41 & 46 & 4 & & 8 & 9 \\
\hline Tamaulipas & 59 & & 75 & 96 & & & 2 & 4 \\
\hline Tepic & - & 289 & 281 & 305 & & 2 & 2 & 5 \\
\hline Tlaxcala & 247 & 441 & 412 & 412 & 2 & 8 & 9 & 9 \\
\hline Veracruz & 178 & 429 & 490 & 415 & 1 & 1 & 1 & 1 \\
\hline Yucatán & & & 301 & 370 & & & 6 & 6 \\
\hline Zacatecas & & & & & & & \\
\hline
\end{tabular}

Fuente: Moisés González Navarro, Estadísticas sociales del porfiriato 1877-1910, México, Talleres Gráficos de la Nación, Secretaría de Economía, México, 1956, p. 13. Para el caso del número de templos católicos ubicados en el estado de Oaxaca hacia 1895, la tabla indica que había 165. Más que tratarse de una estrepitosa caída, es un error en la captura de los datos.

Ciertamente, ni la desamortización (1856) y la nacionalización de bienes eclesiásticos (1859) -y en general las Leyes de Reforma-, inhibieron la posibilidad de las asociaciones religiosa acrecentar su patrimonio. Esta situación no pasó desapercibida para los constituyentes, quienes consideraron que en ese sentido debían ver más allá de la legislación decimonónica y que además estuviera en consonancia con una nueva noción de propiedad. En ese sentido, la nueva noción de propiedad se fundamentó en 4 principales puntos:

1. La propiedad originaria de la tierra pertenece al Estado (nación), y sólo éste puede conferir a los particulares un derecho de propiedad privada, por lo tanto, la propiedad privada deriva de la Nación; 2. La propiedad privada puede estar sometida a todas las restricciones que impone el interés general, previniendo la posesión de grandes extensiones de tierras por un solo propietario; 3 . Las riquezas naturales y aguas territoriales no pueden estar en el régimen de propiedad privada; 4. La nacionalización sólo podrá llevarse a cabo por causa de utilidad pública. ${ }^{25}$

\footnotetext{
${ }^{25}$ Héctor Cuadra Moreno, "Teoría de la nacionalización. (El Estado y la propiedad). Apéndice de Derecho mexicano", en Konstantin Katzarov, Teoría de la nacionalización, México, Universidad Nacional Autónoma de México, 1963, pp. 626634.
} 
Bajo esta perspectiva, únicamente el Estado puede conferir el derecho de propiedad privada, también estaba facultado para discernir a quiénes debía reconocerse la capacidad de adquirir bienes raíces. Cambió entonces la concepción sobre la propiedad privada y los sujetos de derecho que podían acceder a ella. Para el caso de las asociaciones religiosas pasó algo bastante peculiar. En el proyecto de Constitución inicial, la regulación de los bienes destinados al culto público fue establecida en la fracción II y presentada de la siguiente forma:

La Iglesia, cualquiera que sea su credo, no podrá en ningún caso tener la capacidad de administrar bienes raíces ni capitales impuestos sobre ellos. Los templos destinados al culto público son de la propiedad de la Nación representada por el Gobierno Federal, quien determinará los que deban continuar destinados a su objeto. Los obispados, casas curales, seminarios, asilos o colegios religiosos de asociaciones religiosas o cualquiera otro edificio que hubiese sido construido o destinado a la administración, propaganda o enseñanza de un culto religioso, pasará desde luego de pleno derecho al dominio de la Nación para destinarse exclusivamente a los servicios públicos de la Federación o de los Estados en sus respectivas jurisdicciones. Los templos que en lo sucesivo se erigieren serán propiedad de la Nación, si fueren construidos por suscripción pública; pero si fuesen construidos por particulares quedarán sujetos a las prescripciones de las leyes comunes para la propiedad privada. ${ }^{26}$

No hubo discusión acerca de negarle a las asociaciones religiosas la capacidad de poseer/administrar bienes inmuebles. Tampoco los hubo sobre nacionalizar dichos capitales. En realidad la propuesta de adhesión más controvertida sobre el tema la presentó el diputado Samuel de los Santos, quien propuso que a partir de la promulgación de la nueva Constitución no se permitiera la construcción de ningún templo, independientemente el culto. Sin embargo, Francisco Mújica comentó que previamente se había aprobado una solicitud de una colonia de judíos rusos para colonizar una región del país, garantizándole también el permiso para erigir templos. Sin embargo, la intervención de Samuel de los Santos sirvió para definir el estatus que tendrían los templos en lo sucesivo, se resolvió que si bien no se prohibiría su construcción, siempre y cuando se registraran a favor de la nación. Hechos las críticas y adhesiones a la propuesta inicial de la fracción II del artículo II, se pasó a la nueva redacción, la cual quedó de la siguiente manera:

Las asociaciones religiosas denominadas iglesias, cualquiera que sea su credo, no podrán en ningún caso tener capacidad para adquirir, poseer o administrar bienes raíces, ni capitales impuestos sobre ellos; los que tuvieren actualmente, por sí o por interpósita persona entrarán al

${ }^{26}$ F.F. Palavicini, Historia de la, p. 616. 
dominio de la Nación, concediéndose acción popular para denunciar los bienes que se hallaren en tal caso. La prueba de presunciones será bastante para declarar fundada la denuncia. Los templos destinados al culto público son de la propiedad de la Nación, representada por el Gobierno Federal, quien determinará los que deben continuar destinados a su objeto. Los obispados, casas curales, seminarios, asilos o colegios o asociaciones religiosas, conventos o cualquier otro edificio que hubiere sido construido o destinado a la administración, propaganda o enseñanza de un culto religioso, pasarán desde luego, de pleno derecho, al dominio directo de la Nación, para destinarse exclusivamente a los servicios públicos de la Federación o de los Estados en sus respectivas jurisdicciones. Los templos que en lo sucesivo se erigieren para el culto público, serán propiedad de la nación. ${ }^{27}$

Pareciese pensar que con la nacionalización de bienes, las asociaciones religiosas iban a ser desprovistas de sus capitales inmobiliarios, además de que limitar su participación en negociaciones mercantiles y limitar su intervención en el espacio público, dado que a partir de la entrada en vigencia del nuevo marco jurídico, se debía pedir permiso para erigir templos.

\section{5.- El sometimiento de las Iglesias al poder civil: artículo 130}

Pese a que el tema de los bienes de las asociaciones religiosas fue un tópico delicado y que al final el constituyente adoptó una postura más radical con respecto a la Constitución de 1857 y las Leyes de Reforma, no se compara con las ámpulas que despertó el proyecto de artículo 129. Como ya se ha mencionó, la Iglesia católica había sido señalada como colaboradora de la administración huertista. Algunas facciones revolucionarias no se limitaron a señalar a dicha institución como aliada del usurpador, sino que adoptaron actitudes hostiles y netamente anticlericales, de ahí que sorprenda que el proyecto de artículo 129 se limitara a incluir las Leyes de Reforma, que, por cierto, ya se habían elevado a rango constitucional en 1873. Sin embargo, el proyecto fue ampliamente criticado en la asamblea general, puesto que no correspondía con el ánimo anticlerical que estaba dispuesto a ir más allá que los constituyentes de 1857 y las Leyes de Reforma. Era su oportunidad de poner a raya a la Iglesia católica, y no querían desaprovecharla. El proyecto de artículo 129 fue presentado de la siguiente forma:

Corresponde exclusivamente a los poderes federales ejercer en materia de culto religioso y disciplina externa, la intervención que designen las leyes. El Estado y la Iglesia son independientes entre sí. El Congreso no puede dictar leyes estableciendo o prohibiendo religión alguna. El

\footnotetext{
27““Constitución Política de los Estados Unidos”, p. 151.
} 
matrimonio es un contrato civil. Éste y los demás actos del Estado civil de las personas, son de exclusiva competencia de los funcionarios y autoridades del orden civil en los términos prevenidos por las leyes, y tendrán la fuerza y validez que las mismas les atribuyen. La simple promesa de decir verdad y de cumplir las obligaciones que se contraen, sujeta al que la hace, en caso de que faltare a ella, las penas que con tal motivo establece la ley. ${ }^{28}$

El proyecto presentado por Carranza no respondía a las exigencias de los constituyentes, quienes vieron se opusieron a aprobar el proyecto e iniciar las discusiones que permitieran delinear de mejor manera el artículo 129. Una primera cuestión -y que había quedado pendiente de discutir-fue la supresión de la confesión auricular. El primero en ocupar la tribuna fue Modesto González Galindo, quien inició su participación diciendo: “yo vengo a hablar aquí sin temor a las censuras, sin temor a la excomunión, sin temor al infierno, sin temor a la condenación externa". ${ }^{29}$ Después de hacer alusiones históricas sobre el cristianismo, retomó el tema de la abolición de la confesión auricular, debido a que esta práctica se prestaba a grandes crímenes, inmoralidades y conspiraciones contra el Estado. Prosiguió aclarando...

...no quiero atacar la confesión por lo que tiene de dogmática sino por lo que tiene de instrumento político...La confesión auricular se presta para cometer crímenes, para conspirar y, por esta razón, ya no como dogma, ya no como doctrina, que en ese caso tendía razón de ser; pero en el sentido político, cuando se coge como instrumento de conspiración, debemos declararla abolida". ${ }^{30}$

Finalmente, señaló que con la prohibición de la confesión auricular se emanciparía a la mujer del yugo clerical, dado que eran el instrumento utilizado por la Iglesia para logar sus fines políticos, y en ese sentido, González Galindo preguntó a sus compañeros ¿Por qué no hemos de arrebatar a la mujer del confesionario, ya que le arrebatan el honor de su hogar, valiéndose de la confesión auricular? Nosotros debemos prohibir ese acto que se llama confesión auricular, porque es una gran inmoralidad". ${ }^{31} \mathrm{La}$ conceptualización de la cercanía de las mujeres con el clero estuvo en sintonía con la retórica católica de principios del siglo XX, que "representaba a la mujer como un ser débil y fácilmente corruptible, pero también potencialmente seductora y corruptora". ${ }^{32}$

\footnotetext{
${ }^{28}$ Ignacio Marván Laborde, Nueva edición del Diario de Debates del Congreso Constituyente de 1916-1917, tomo III, 2006, pp. 2531-2532.

${ }^{29}$ I. Marván, Nueva edición del, p. 2539.

${ }^{30}$ I. Marván, Nueva edición del, p. 2541.

${ }^{31}$ I. Marván, Nueva edición del, p. 2542

32 Boylan, Kristina A., "Género, fe y nación, El activismo de las católicas mexicanas, 1917-1940", en Gabriela Cano, Mary Kay Vauhgan y Jocelyn Olcott, (coords.), Género, poder y política en el México posrevolucionario, México, Fondo de Cultura Económica-Universidad Autónoma Metropolitana-Iztapalapa, 2011, p. 313.
} 
Por su parte David Pastrana Jaimes enfatizó que debía retomarse el tema del divorcio, señalando que el matrimonio es un contrato civil disoluble, y que "todos los revolucionarios saben perfectamente que se ha expedido una ley que consigna el divorcio y es de todo punto indispensable elevar a precepto constitucional ese principio que es una de las principales causas de la revolución constitucionalista". ${ }^{33}$ Dicho lo anterior, consideró que el pueblo de México no era religioso, sino fanático, siendo el principal problema que el clero católico ha sido históricamente enemigo del gobierno y, por ende, se debe reglamentar su ejercicio. En ese sentido, propuso que "el clero se declare independiente del papado. Aceptemos esta adición y así enseñaremos al clero mexicano la nueva aurora por donde debe orientarse y le enseñaremos esa aurora para que conozca el camino de su independencia y su autonomía". ${ }^{34}$

Tocó el turno de hacer uso de la voz a José Álvarez y Álvarez, quien señaló que el problema de México no es religioso, sino político. A su perspectiva, el clero era una institución nociva para la sociedad, que se había empeñado en explotar a la población, enemiga de la revolución y del gobierno. Para contrarrestar lo anterior, el Estado debía reglamentar el ministerio, es decir, tratarlos como a todos los profesionistas. La propuesta de Álvarez fue la de fijar un número límite de sacerdotes que podrían ejercer las actividades correspondientes a su credo, puesto que eran una "inmensa multitud de zánganos que viven sin trabajar, a costillas de la sociedad. A costillas de todos". ${ }^{35}$ No se hicieron alusiones sobre el dogma, únicamente a que se combatiera a los ministros de culto dentro de los términos del liberalismo. Finalizó señalando que la postura que debían sostener los revolucionarios sobre el clero, al enfatizar que "queremos que se acabe esa plaga y que desaparezca de la República; nosotros vendremos a sostener las más radicales de las reformas y autorizar las medidas, más enérgicas para quitar esa plaga de encima". ${ }^{36}$

En tanto, Félix F. Palavicini orientó su participación a perfilar qué tipo de clero se debía autorizar para ejercer su ministerio. Más allá de las posturas anticatólicas, Palavicini indicó que "la religión católica en este pueblo es la única perdurable. Cuando quitéis los fantasmas de este pueblo lo atractivo de la religión católica, habrá perdido por completo el sentimiento fuerte y poderoso que desde la infancia trae y que lo lleva hasta la muerte" ${ }^{37}$. Su postura fue la de no reglamentar el número máximo de ministros de culto que podrían desempeñar su ministerio, puesto que el Estado no podía fijar la dosis

\footnotetext{
${ }^{33}$ I. Marván, Nueva edición del, p. 2542. La ley a la que hizo referencia Pastrana Jaimes fue la "Ley sobre el divorcio", publicada en 1914 por Venustiano Carranza en su carácter de Primer Jefe del Ejército Constitucionalista. Aunque se debe aclarar que la promotora de dicha disposición fue Hermila Galindo.

${ }^{34}$ I. Marván, Nueva edición del, pp. 2544-2445.

${ }^{35}$ I. Marván, Nueva edición del, p. 2547

${ }^{36}$ I. Marván, Nueva edición del, p. 2549.

${ }^{37}$ I. Marván, Nueva edición del, p. 2556.
} 
de religión de los individuos. La posición de Palavicini al respecto fue que se incluyera un requisito fundamental para poder ejercer como ministro de culto: ser mexicano de nacimiento.

El último en hablar fue Francisco J. Mújica, el más enérgico de los constituyentes en contra de la Iglesia católica. Había estado en los debates del artículo $3^{\circ}$ y 27 , y todo parecía indicar que lideraría al ala radical para reformar el proyecto de artículo 129. Sin embargo, más que realizar propuestas de adición, su participación se limitó a refrendar su apoyo para que fuese abolida la confesión auricular y que se limitara el número de sacerdotes. Cabe resaltar que no tuvo reparo en descalificar a los ministros de culto, comentando que "deberían llamarse una banda de ladrones, de forajidos y estafadores, porque los curas en México no han sido otra cosa que estafadores del dinero de los trabajadores para poder enriquecerse y darse una gran vida". 38 Finalmente, encomió a los demás diputados a seguir el propósito firme de "no descansar hasta que no hagamos desaparecer al pequeño número de vampiros que tenemos en México, y hasta que nos consigamos exterminarlos, porque para mí, señores, lo confieso, sería lo ideal". 39

Escuchadas todas las voces que quisieron participar en el debate, se llevó a votación el dictamen del artículo 129 con severas restricciones para la Iglesia católica y las asociaciones religiosas en general. En primer lugar, se confirmó que correspondería a los poderes federales ejercer en materia de culto religioso y disciplina externa; el matrimonio es un contrato civil; no se reconocería la personalidad jurídica de ninguna asociación religiosa; los ministros de cultos serían considerados como personas que ejercen una profesión; las legislaturas de los estados tendrían la facultad de determinar el número máximo de ministros de culto, los cuales debían acreditar ser mexicanos de nacimiento; quedó prohibido que los ministros de culto hicieran críticas al gobierno, se les restringió el derecho a votar, no podrían ser susceptibles a ser herederos, por testamento o por interpósita persona. A su vez, se prohibieron todas las publicaciones periódicas de carácter confesional, quedando también restringidas las agrupaciones políticas en cuyo título tenga alguna palabra o indicación que la relacione con alguna confesión religiosa; se estableció que los bienes e inmuebles del clero y de las asociaciones religiosas quedarían regulados en la fracción II del artículo 27. Por último, se indicó que la autoridad que la autoridad que infringiera las anteriores disposiciones, sería penalmente responsable. ${ }^{40}$

\footnotetext{
${ }^{38}$ I. Marván, Nueva edición del, p. 2564.

${ }^{39}$ I. Marván, Nueva edición del, p. 2563

40 “Constitución Política de los Estados Unidos Mexicanos”, pp. 159-160.
} 
La Constitución se promulgó el 5 de febrero de 1917. Lo que fue el proyecto de artículo 129 se convirtió en el 130. Pese a la vehemencia de Modesto González Galindo para que se prohibiera la confesión auricular, su propuesta no fue aprobada. Aún así, el panorama para las asociaciones religiosas no pintaba bien. El Estado no únicamente no las reconocería jurídicamente, sino que se reservó para sí la facultad de determinar el número máximo de ministros de culto que podían desempeñar su ministerio; se decretó la nacionalización de todos los bienes destinados al culto público que existían y los que se construyesen en lo sucesivo; se limitó severamente la participación de las Iglesias en el ámbito educativo, a lo que se debía sumar las restricciones políticas impuestas para las asociaciones religiosas y los ministros de culto. La Constitución de 1917 no representó secularizar la vida pública y privada de México, sino que fue más allá. Se trató del sometimiento legal del Estado sobre las asociaciones religiosas y ministros de culto, en donde asumió la tarea de educar y moralizar a los mexicanos a partir de doctrinas laicas que combatieran el atraso y conservadurismo encarnado por el clero. En ese sentido, cabe preguntarse cuál fue la respuesta de la Iglesia a la Constitución del 5 de febrero de 1917.

\section{6.- Respuesta del episcopado a la Constitución de 1917}

El episcopado mexicano, si bien estaba en el exilio al momento de la promulgación, no quedó impávida ante el nuevo marco legal y la nueva dinámica que se proponía en cuestión religiosa. La Constitución fue publicada el 5 de febrero de 1917 en el Diario Oficial de la Federación, entrando en vigor el 1 de mayo. La respuesta del episcopado fue bastante rápida, publicando la "Carta Pastoral Colectiva del Episcopado Mexicano sobre la Constitución de 1917” el 24 de febrero en El Universal. El documento inicia señalando que "después de haber sufrido por tres años las angustias consiguientes a los males gravísimos que la peste, el hambre, la guerra y la persecución religiosa han llevado a los fieles de nuestras diócesis, una pena más grave ha venido a empeorar nuestra amarga situación". ${ }^{41}$ La Constitución representó -siguiendo el planteamiento de la protesta- elevar el acosamiento religioso, suprimiendo las pocas prerrogativas que les había dejado la Constitución de 1857. La protesta incluyó las siguientes declaraciones por parte de los prelados:

$1^{\text {a }}$. Que conforme con las doctrinas de los Romanos Pontífices, especialmente la contenida en la Encíclica Quod Apostolici muneris, y movidos también por patriotismo, nos hallamos muy lejos de aprobar la rebelión armada contra la autoridad constituida, sin que esta sumisión pasiva a cualquier gobierno signifique aprobación o aceptación

\footnotetext{
${ }^{41}$ Nestor García Cantú, El pensamiento de la reacción mexicana. Historia documental. Tomo segundo (1860-1926), México, Universidad Nacional Autónoma de México, 1994, p. 281.
} 
intelectual y voluntaria a las leyes antirreligiosas o de otro modo injustas que de él emanaren, y sin que por ella se pretenda que los católicos, nuestros fieles, deban privarse del derecho que les asiste como ciudadanos, para trabajar legal y pacíficamente por borrar de las leyes patrias, cuanto lastime su conciencia y su derecho.

$2^{\mathrm{a}}$. Que en este nuestro proceder, no nos mueve ni el más ligero deseo de venganza, ni siquiera el natural empeño de procurar el bienestar temporal nuestro y de nuestro clero (que para conseguirlo, más nos valdría transigir o callar), sino que tenemos por único móvil, cumplir con el deber que nos impone la defensa de los derechos de la Iglesia y de la libertad religiosa. ${ }^{42}$

A diferencia del posicionamiento beligerante que la Iglesia católica asumió con la Constitución de 1857, en 1917 no aprobó institucionalmente métodos violentos para hacerle frente al nuevo marco normativo, sino que declararon que su posicionamiento fue el de defender los derechos de la Iglesia. En ese se sentido, condenaron lo contenido en varios artículos constitucionales: $3^{\circ}$, $5^{\circ}, 27,31$ y 130 . Fue en este último precepto el que tuvo más críticas debido a que, a opinión de los prelados firmantes, volvía en ilusoria la libertad religiosa. Los obispos se preguntaron “¿Qué queda de la libertad de adorar a Dios? ¿No es esto destruir en su esencia la sociedad religiosa, de suyo independiente del Estado? ¿No es sujetar la conciencia individual en sus relaciones con Dios, a los poderes públicos? ¿No es esclavizar al poder del Estado no sólo la Iglesia, no sólo al Clero, como se pretende hacer creer, sino los católicos todos, los hombres todos que tengan religión? ¿Y hacer esto, no es tiranía?" 43 El documento fue firmado por los arzobispos José Mora y del Río (México), Leopoldo Ruiz y Flores (Michoacán), Francisco de Paula Mendoza y Herrera (Durango), Martín Tritschler y Córdova (Yucatán), Francisco Plancarte (Linares), los obispos Francisco Uranga Sáenz (Sinaloa), José Juan Herrera y Piña (Tulancingo), Vicente Castellano y Núñez (Campeche), Maximino Ruiz y Flores (Chiapas), Ignacio Valdespino (Aguascalientes) y Miguel M. de la Mora (Zacatecas), así como Manuel Reinoso, vicario capitular de Querétaro y Martín Portela, vicario de ,a sede vacante de Sonora. Pese a lo anterior, "la respuesta de los prelados no fue lo suficientemente agresiva como pudiera esperarse debido, muy probablemente, a la vulnerable situación que enfrentaba la jerarquía. Si querían regresar al territorio mexicano tenían que ser cuidadosos en la forma de defender sus derechos". ${ }^{44}$

Debe agregarse que pese a la vehemencia con la que los prelados condenaron la Constitución de 1917, la protesta careció de un plan de acción dirigido a los católicos, es decir, las críticas no fueron acompañadas de directrices

\footnotetext{
${ }^{42}$ N. García Cantú, El pensamiento de, p. 282.

${ }^{43}$ N. García Cantú, El pensamiento de, p. 288.

${ }^{44}$ María Gabriela Aguirre Cristiani, "La jerarquía católica en el exilio frente al nuevo marco jurídico revolucionario de 1917”, en Política y Cultura, No. 48, 2017, p. 164.
} 
generales que los fieles pudiesen seguir con el fin de también adherirse a las críticas. Además, no se incluyeron propuestas de reformas en las que la Iglesia estarían de acuerdo, y, por último, "la ausencia de oficio diplomático tanto fuera como dentro del país se dejó ver en la nueva norma jurídica que la Revolución hizo viable y en la que, como se ha visto, la Iglesia católica salió muy afectada". ${ }^{45}$

Por su parte, la Santa Sede apoyó el reclamo hecho por el episcopado mexicano. Oficialmente, el Papa Benedicto XV "se sumó a la iniciativa de los obispos mexicanos con la epístola Exploratum vobis est (15 de junio de 1917)". ${ }^{46}$ El documento confirma el posicionamiento de la Iglesia hecho el 24 de febrero de 1917, además de encomiar a los católicos a afrontar estoicamente los atropellos perpetrados por los revolucionarios, tanto en el plano social como en el legal.

La protesta no fue bien vista por Carranza "ya que al momento de su publicación, agitó el ambiente católico en su contra y fue muy difundida en el suelo mexicano". ${ }^{47}$ También hubo críticas hacia los prelados. El 3 de julio de 1917 apareció un artículo en el diario El Universal reprobando la actitud de los obispos exiliados en el tenor siguiente:

Ninguno de los prelados en exilio ha estado a la altura de las inmortales enseñanzas que guarda en sus fastos la historia de la Iglesia Católica. Pues bien, estos prelados "PROTESTANTES", huyeron, dejando en el abandono a la desolada grey, en vez de morir valientemente y cristianamente si el caso llegaba, a la cabeza de ella. ¡Qué no tienen vocación de mártires! Muy bien, pero entonces que dejen la carrera: EL SACERDOTE CATÓLICO ES UN MILICIANO DE CRISTO, y el valor heroico debe ser una cualidad profesional. ¡Cuánto más debe pedirse a un Obispo o a un Arzobispo, como si dijéramos a un General de Brigada, un Divisionario de la Católica hueste. Estos señores prefirieron salvar la mísera carne, caso de que esta realmente peligrara, carne que se mostró FLACA SIN QUE EL ESPÍRITU ESTUVIESE PRESTO, para ajustarse a la evangélica enseñanza. Con sutilezas canónicas quizá intentarán defenderse: en puridad cristiana, SON SIMPLES DESERTORES, a quienes no animó en época trágica el sublime espíritu del Divino Maestro. ${ }^{48}$

\footnotetext{
${ }^{45}$ M.G. Aguirre Cristiani, "La jerarquía católica”, p. 163.

${ }^{46}$ Paolo Valvo, "De Querétaro a Versailles. La Santa Sede y la Constitución mexicana (1917-1920)", en Óscar Cruz Barney y Miguel Carbonell (eds.), Historia y Constitución. Homenaje a José Luis Soberanes Fernández, tomo III, México, Instituto de Investigaciones Históricas UNAM, 2015, p. 397.

47 Mario Ramírez Rancaño, La reacción mexicana y su exilio durante la Revolución de 1910, México, Instituto de Investigaciones Históricas UNAM, 2002, pp. 320-321.

${ }^{48}$ Carlos Francisco Vera Soto, La formación del clero diocesano durante la persecución religiosa en México, 1910-1940, México, Universidad Pontificia de México, 2005, pp. 289-290.
} 
Si bien el artículo no fue firmado, representó una dura crítica a la decisión de la mayoría del episcopado que decidió exiliarse. Algunos obispos como Miguel M. de Mora habían intentado regresar a sus diócesis durante el periodo de 1914-1917, sin embargo, no lograron su propósito. El retorno de los obispos se dio a partir de la promulgación de la Constitución, cuando las condiciones políticas se habían relajado y el ambiente militar se atenuó. Los prelados tuvieron el reto de pensar cómo hacerle frente al nuevo marco normativo, desde la reanudación de los seminarios, reorganización de las parroquias, cómo organizar las tradicionales peregrinaciones y, en general, cómo desarrollarían sus actividades de culto público en el marco de la nueva Constitución.

\section{Reflexiones finales}

El movimiento revolucionario trató de sentar las bases de una sociedad más justa y con mejores condiciones sociales y materiales para los desposeídos. La cuestión religiosa también fue un tópico importante en el Congreso Constituyente, debido a que se consideró que debía quedar asentada la supremacía del Estado sobre las asociaciones religiosas, especialmente la católica, con el propósito de sujetarlas política, económica y socialmente. A diferencia de la legislación decimonónica que les permitió a las Iglesias desarrollarse con ciertas limitaciones, la Constitución de 1917 les negó el reconocimiento jurídico, les prohibió poseer y/o administrar bienes inmuebles y supeditó su participación en el ámbito educativo, tanto en el establecimiento de escuelas particulares como en el funcionamiento regular de los seminarios.

La Constitución de 1917 representó una bomba, pero alguien debía encender esa mecha. Y fue exactamente el principal problema que tuvo el nuevo marco normativo en la cuestión religiosa: ¿Cómo se aplicarían los artículos que regulaban a las Iglesias y ministros de cultos? No hubo mayor problema para los artículos $5^{\circ}$ y 24 , puesto que se refrendó lo estipulado en la legislación decimonónica, sin embargo, las 3 disposiciones restantes se requería legislación secundaria. La encrucijada del Estado fue encontrar quién tendría la voluntad para hacer valer el nuevo marco legal, puesto que la hacerlo se vería enfrentado contra las asociaciones religiosas y sus respectivos fieles.

Por ejemplo, en relación a la educación confesional, se planteó una disyuntiva que impedía el funcionamiento de los seminarios "puesto que los edificios ostensiblemente destinados a este fin son declarados propiedad de la Nación y los pertenecientes a otras personas, por el hecho de que los arrendatarios los destinen a fin expresado, incurren también en causa de nacionalización". ${ }^{49}$

${ }^{49}$ Efraín González Luna, Los católicos y la política mexicana. Condición política de los católicos mexicanos, México, Editorial Jus, 1988, p. 55. 
Había la necesidad de establecer claramente las formas en que el Estado iba a reglamentar los artículos $3^{\circ}, 27$ y 130, lo cual no se dio pronto. El hacerlo suponía enfrentarse directamente con la Iglesia católica y los fieles.

El encontronazo más sonado sucedió durante la presidencia de Plutarco Elías Calles. Pese a que durante el periodo de 1917-1925 se dieron algunos malentendidos entre el Estado, la Iglesia y los católicos, aún no se publicaba ninguna reglamentación secundaria de los artículos que regulaban la cuestión religiosa, sin embargo, a partir de las declaraciones del arzobispo de México hechas el 7 de enero de 1926 "en las que afirmaba se combatirían las medidas lascivas a la religión. En realidad habían sido hechas antes, pero preguntando ahora por el periodista si las ratificaba lógicamente lo hizo" ${ }^{50}$ La respuesta de Calles fue la expulsión de los ministro de culto extranjeros y la publicación de la Ley que reformó el Código Penal sobre delitos del fuero común y delitos contra la Federación en materia de culto y disciplina externa -mejor conocida como la Ley Calles - (2 de julio de 1926), la cual es considerada como ley reglamentaria del artículo 130 constitucional. Esta disposición confirmó lo estipulado en los artículos $3^{\circ}, 5^{\circ}, 24$, fracción II del 27 y 130, estableció las competencias de la Federación, estados y municipios para hacer cumplir la ley y fijó multas a los infractores y a autoridades omisas. En respuesta de lo anterior, el episcopado mexicano anunció la suspensión del culto público a partir del 31 de julio de 1926. Ante el abandono de los templos por parte de los ministros de culto, autoridades civiles y militares se apresuraron a levantar inventarios de los inmuebles y nombrar juntas vecinales para su administración provisional. Los fieles católicos interpretaron esta acción como un nuevo acto de nacionalización, iniciando movilizaciones que dieron como resultado un conflicto armado que pasó a denominarse Guerra Cristera (1926-1929) en el que se han estimado que murieron más de 200 mil personas.

\section{Bibliografía}

Aguirre Cristiani, María Gabriela, "La jerarquía católica en el exilio frente al nuevo marco jurídico revolucionario de 1917”, en Política y Cultura, No. 48, 2017, pp. 161-176.

Barbosa Guzmán, Francisco, "Católicos y Revolución mexicana", en IglesiaRevolución mexicana. Jornada Académica, Guadalajara, Departamento de Estudios Históricos de la Arquidiócesis de Guadalajara/Dirección de Cultura del Ayuntamiento de Guadalajara, 2010, pp. 91-128

\footnotetext{
${ }^{50}$ Luis Rubio Hernansáez, Contrarrevoluciones católicas. De los chuanes a los cristeros (1792.1942), Zacatecas, Texere, 2017, p. 508.
} 
Bastian, Jean Pierre, Los disidentes. Sociedades protestantes y revolución en México, 1872-1911, México, Fondo de Cultura Económica/El Colegio de México, 1989, pp. 373.

Boylan, Kristina A., "Género, fe y nación, El activismo de las católicas mexicanas, 1917-1940", en Gabriela Cano, Mary Kay Vauhgan y Jocelyn Olcott, (coords.), Género, poder y política en el México posrevolucionario, México, Fondo de Cultura Económica-Universidad Autónoma Metropolitana-Iztapalapa, 2011, pp. 309-346.

Cárdenas García, Nicolás y Guerra Manzo, Enrique, "De revolucionarios a legisladores. El proceso político del Congreso Constituyente de 1916-1917", en Política y Cultura, No. 48, 2017, pp. 9-36.

Cuadra Moreno, Héctor, "Teoría de la nacionalización. (El Estado y la propiedad). Apéndice de Derecho mexicano", en Konstantin Katzarov, Teoría de la nacionalización, México, Universidad Nacional Autónoma de México, 1963, pp. 624-666.

"Constitución Política de los Estados Unidos", en Diario Oficial de la Federación, 5 de febrero 1917, pp. 149-161.

"Decreto sobre desamortización de fincas rústicas y urbanas que administren como propietarios las corporaciones civiles y eclesiásticas", en Manuel Dublán y José Ma. Lozano, (comp.), Legislación mexicana o colección completa de las disposiciones legislativas expedidas desde la Independencia de la República, México, Imprenta del Comercio de E. Dublán y Comp., t. VIII, 1877, pp. 197200.

García Cantú, Néstor, El pensamiento de la reacción mexicana. Historia documental. Tomo segundo (1860-1926), México, Universidad Nacional Autónoma de México, 1994, pp. 402.

González Luna, Efraín, Los católicos y la política mexicana. Condición política de los católicos mexicanos, México, Editorial Jus, 1988, pp. 85.

González Navarro, Moisés, Estadísticas sociales del porfiriato 1877-1910, México, Talleres Gráficos de la Nación, Secretaría de Economía, México, 1956, pp. 125.

Knight, Alan, "Caudillos y campesinos en el México revolucionario, 1910-1917”, en David Brading (Comp.), Caudillos y campesinos en la Revolución Mexicana, México, Fondo de Cultura Económica, 1985, pp. 32-85.

Lara Bravo, Alonso, Libertad religiosa en México, México, Comisión Nacional de Derechos Humanos, 2015, pp. 46.

Magallanes Delgado, María del Refugio, La educación laica en México. La enseñanza de la moral práctica XIX-XX, Zacatecas, Policromía, 2016, pp. 191.

Marino, Daniela y Zuleta, María Cecilia, "Una visión del campo. Tierra, propiedad y tendencias de la producción, 1850-1930”, en Sandra Kuntz Ficker (coord.), 
Historia económica de México. De la colonia a nuestros días, México, El Colegio de México, 2010, pp. 437-472.

Padilla Rangel, Yolanda, Los desterrados. Exiliados católicos de la Revolución Mexicana en Texas, 1914-1919, Aguascalientes, Universidad Autónoma de Aguascalientes, 2009, pp. 249.

Palavicini, Félix F., Historia de la Constitución de 1917, México, SEP/INEHRM, 2015, t. I, pp. 675.

Ramírez Rancaño, Mario, La reacción mexicana y su exilio durante la Revolución de 1910, México, Instituto de Investigaciones Históricas Universidad Nacional Autónoma de México, 2002, pp. 463.

Rodríguez Carvajal, Francisco J., "La libertad religiosa en las Constituciones de 1857 y 1917", en Quórum legislativo. Revista del Centro de Estudios de Derecho e Investigaciones Parlamentarias, No. 118, 2017, pp. 123- 158.

Roauix, Pastor, Génesis de los artículos 27 y 123 de la Constitución Política de 1917, México, INEHRM, 2016, pp. 400.

Romero de Solís, José Miguel, El Aguijón del espíritu. Historia contemporánea de la Iglesia en México (1892-1992), México, Instituto Mexicano de Doctrina Social Cristiana, Colegio de Michoacán, Archivo Histórico del Municipio de Colima, Universidad de Colima, 2006, pp. 750.

Rubio Hernansáez, Luis, Contrarrevoluciones católicas. De los chuanes a los cristeros (1792.1942), Zacatecas, Texere, 2017, pp. 609.

Soto Flores, Antonio, "El artículo $3^{\circ}$. Constitucional. Un debate por el control de las conciencias", en Cuestiones Constitucionales. Revista Mexicana de Derecho Constitucional, No. 28, 2013, pp. 211-240.

Urquizo, Francisco L., Carranza. El hombre. El político. El caudillo. El patriota, México, SEP/INEHRM, 2015, pp. 101.

Valvo, Paolo, "De Querétaro a Versailles. La Santa Sede y la Constitución mexicana (1917-1920)", en Óscar Cruz Barney y Miguel Carbonell (eds.), Historia y Constitución. Homenaje a José Luis Soberanes Fernández, tomo III, México, Instituto de Investigaciones Históricas UNAM, 2015, pp. 393-435.

Vera Soto, Carlos Francisco, La formación del clero diocesano durante la persecución religiosa en México, 1910-1940, México, Universidad Pontificia de México, 200, pp. 1446.

Villegas Martínez, Fernando, “Tiempos difíciles”, en Villegas Martínez, Fernando et al., La sabiduría se edificó una casa. Apuntes para la historia del Seminario Conciliar de Zacatecas, Zacatecas, Taberna libraria editores, 2019, pp. 45-64. 
Zarco, Francisco, Historia del Congreso Extraordinario Constituyente de 1856 y 1857: extracto de todas sus sesiones y documentos parlamentarios de la época. México, Imprenta de Ignacio Cumplido. 1857. Tomo 1, pp. 1009. 